\title{
The Direction of Tax Policy in 2021 in the Context Increase Tax Revenue in the 19th COVID Recovery
}

\author{
Agus Subagiyo $^{1}$, Diana Prihadini ${ }^{2}$, Mainita Hidayati ${ }^{3}$, \\ Dwikora Hardjo ${ }^{4}$, Pebriana Arimbhi ${ }^{5}$ \\ ${ }^{12345}$ The STIAMI Institute for Social Sciences and Management.
}

Submitted : September 25, 2020 Revised : October 10, $2020 \quad$ Published : October 31, 2020

\begin{abstract}
The COVID-19 pandemic has changed economic and social developments and arrangements throughout the world. This pandemic requires the Government together with elements of the community to make efforts to prevent the spread of the virus and economic recovery. In the context of maintaining sustainable development in the midst of dynamic fundamental challenges, the National Budget as an instrument of fiscal policy is designed to be more productive, effective, and efficient in order to accelerate economic growth for welfare and improve the government's balance sheet. Global economic activity has been disrupted due to lockdown policies in a number of Indonesia's major trading partners, which has reduced supply of important components for industries from abroad. The increasing exchange rate of the US dollar makes the price of imported materials more expensive. On the consumption side, many companies experience cash flow difficulties, thereby reducing their ability to pay taxes resulting in significant tax revenues such as Corporate Income Tax. Significant reduction in international trade activities also resulted in lower tax revenues from imports and import duties. Tax revenues also experienced pressure from falling world oil prices, minerals, and CPO which are important components in calculating oil and gas PPh and export duties. Tax revenue performance is expected to weaken in 2020 with a tax ratio potentially below 9 percent. The government has made the first policy of relaxing the taxation by reducing the burden of business activities and helping to improve the condition of the company's cash flow, especially during and after the COVID-19 epidemic. The company can use a reduction in corporate income tax rates, exemption from import $\mathrm{PPh}$ and certain sector import duties, as well as various other tax facilities to cover increases in input material prices and decreased sales so that it continues to operate normally. Both Governments have made efforts to expand the taxation base and improve tax administration. Third The addition of new tax objects, one of which the Government levies taxes on Trade through Electronic Systems (PMSE) and other object sources of excise products such as plastics, sweetened drinks, and fuel oil (BBM). Fourth, from the aspect of tax subject by extending the taxpayers (WP), which are sector-based and regional, increase WP voluntary compliance through effective education and service improvement, including the High Net Worth Individual (HNWI) group. The Fifth Government seeks to improve tax governance and administration starting from business processes, information technology, databases (core tax), organizations, and HR. From government policies in the effort to accelerate economic recovery, there are still various obstacles, especially in terms of regulations or policies prepared as well as technology as a means of infrastructure in supporting these regulations. The regulation or policy must touch on all aspects, namely aspects of tax law, aspects of tax justice, and aspects of the Double Tax Avoidance Agreement (P3B) for cross-border transactions.
\end{abstract}

Keywords: Tax Policy, Tax Revenue, 19th Covid Recovery 
The Direction of Tax Policy in 2021 in the Context Increase Tax Revenue in the 19th COVID Recovery Subagiyo, Prihadini, Hidayati, Hardjo, \& Arimbhi

\section{INTRODUCTION}

The COVID-19 pandemic has changed economic and social developments and arrangements throughout the world. This pandemic requires the Government together with elements of the community to make efforts to prevent the spread of the virus and economic recovery. In order to maintain sustainable development in the midst of dynamic fundamental challenges, the National Budget as an instrument of fiscal policy is designed to be more productive, effective, and efficient in order to accelerate economic growth for welfare and improve the government's balance sheet. Global economic activity has been disrupted due to lockdown policies in a number of Indonesia's major trading partners, which has reduced supply of important components for industries from abroad.

The increasing value of the US dollar makes the price of materials more expensive. On the consumption side, many companies increase cash flow difficulties and therefore lose the ability to receive taxes that receive tax revenues such as $\mathrm{PPh}$. Reduced international trade activities also significantly reduce important revenue taxes and import duties. Tax revenues also reduce world oil prices, minerals, and $\mathrm{CPO}$ which are important components in the calculation of oil and gas $\mathrm{PPh}$ and export duties.

\section{METHOD}

The purpose of this research is to find out the direction of tax policy in 2021 in order to increase tax revenue during the Covid-19 pandemic in Indonesia. In this writing the researcher used a study literature that is in the process of taking the data researchers do not need to go directly into the field but take various reference sources that support this research.

This type of research is qualitative research. Data collection techniques are listening and recording important information in conducting data analysis by means of data reduction, data display and conclusions so as to get a picture of conclusions about the study of literature to be developed in this study and to validate the data using triangulation of data sources.

\section{RESULTS AND DISCUSSION}

The government has made the first policy of relaxing the taxation by reducing the burden of business activities and helping to improve the condition of the company's cash flow, especially during and after the COVID-19 epidemic. Both Governments have made efforts to expand the taxation base and improve tax administration. Third The addition of new tax objects, one of which the Government levies taxes on Trade through Electronic Systems (PMSE) and other object sources of excise products such as plastics, sweetened drinks, and fuel oil (BBM). Fourthly, from the aspect of tax subject by extending the taxpayers (WP) based on sector and territorial basis and improving services, including to the High Net Worth Individual (HNWI) group. The Fifth Government seeks to improve tax governance and administration ranging from business processes, information technology, databases (core tax), organizations, and HR.

\section{CONCLUSION}

The COVID-19 pandemic has changed economic and social developments and arrangements throughout the world .

The government has made five policies, the first is to relax taxation especially during and after the COVID-19 epidemic. reduction of corporate income tax rates, exemption from import tax and certain sector import duties, the two governments have made efforts to expand the taxation 
The Direction of Tax Policy in 2021 in the Context Increase Tax Revenue in the 19th COVID Recovery Subagiyo, Prihadini, Hidayati, Hardjo, \& Arimbhi

base and improve tax administration. Third, the addition of new tax objects through the Electronic System (PMSE). Fourth is the extensification of taxpayers (WP) that is sector-based and regional, increasing WP voluntary compliance through effective education and service improvement, including the High Net Worth Individual (HNWI) group. The Fifth Government seeks to improve tax governance and administration starting from business processes, information technology, databases (core tax), organizations, and HR.

\section{REFERENCE}

Albu, L. L., Preda, C. I., Lupu, R., Dobrotă, C. E., Călin, G. M., \& Boghicevici, C. M. (2020). Estimates of Dynamics of the Covid19 Pandemic and of its Impact on the Economy. Romanian Journal of Economic Forecasting, 23(2), 5.

Arboleda, D., \& Zambrano, A. (2020). Vulnerability after covid-19 and the response of a developing city: the case of Bogota, Colombia. Documento CEDE, (36).

Berardi, C., Antonini, M., Genie, M. G., Cotugno, G., Lanteri, A., Melia, A., \& Paolucci, F. (2020). The COVID-19 pandemic in Italy: policy and technology impact on health and non-health outcomes. Health Policy and Technology.

Ekanem, S. A., Imarenezor, E. P. K., \& Okolisah, C. P. (2020). An Essencist Evaluation of SocioEconomic Impacts of Coronavirus Disease (COVID-19) Pandemic in Nigeria. Mediterranean Journal of Social Sciences, 11(5), 70-70.

Ham, A. (2020). Social and economic impact of the COVID-19 and policy options in Honduras.

Kennelly, B., O'Callaghan, M., Coughlan, D., Cullinan, J., Doherty, E., Glynn, L., ... \& Queally, M. (2020). The COVID-19 pandemic in Ireland: An overview of the health service and economic policy response. Health Policy and Technology.

Welfens, P. J. (2020). Corona World Recession and Health System Crisis: Shocks Not Understood So Far (No. disbei273). Universitätsbibliothek Wuppertal, University Library. 